УДК 628.3:001.891

${ }^{[0000-0002-5937-167 X]}$ Т. В. Солодовнік ${ }^{1}$, к.х.н., дочент кафедри хімічних технологій та водоочищення, e-mail: solodovniktetana@gmail.com

${ }^{[0000-0002-7240-5344]}$ Н. М. Толстопалова ${ }^{2}$, к.т.н., доцент, в.о. зав. кафедри технологї̈ неорганічних речовин, водоочищення та загальної хімічної технологї,

${ }^{[0000-0001-6587-6677] ~ Н . ~ М . ~ Ф о м і н а ~} \mathbf{1}$, ст. викладач кафедри хімічних технологій та водоочищення, І. К. Якименко ${ }^{1}$, студентка e-mail: yakimenko97@ukr.net

${ }^{1}$ Черкаський державний технологічний університет б-р Шевченка, 460, м. Черкаси, 18006, Україна

${ }^{2}$ Національний технічний університет України «Київський політехнічний інститут імені Ігоря Сікорського»

просп. Перемоги, 37, м. Київ, 03056, Україна

\title{
ДОСЛІДЖЕННЯ ПРОЦЕСІВ ОЧИЩЕННЯ ЗАБАРВЛЕНИХ РОЗЧИНІВ ПРИ ВИКОРИСТАННІ НЕОРГАНІЧНИХ КОАГУЛЯНТІВ ТА ПРИРОДНОГО ФЛОКУЛЯНТА
}

Проведено дослідження з пошуку ефективних методів очищення забарвлених стічних вод та їх покращення. В ході роботи встановлено переваги та недоліки різних коагулянтів та запропоновано спосіб підвищення ефективності процесу. Як флокулянт використовувався хітозан. Будучи слабким катіонним флокулянтом, хітозан має підвищену ефективність осадження білка порівняно з класичними методами. Визнано за доиільне застосовувати хітозан для вилучення шкідливих домішок з технологічних потоків, які спрямовуються в озера-відстійники $i$ технологічні басейни, а також для скидних вод, щзо витікають з ичих озер у річки. При проведенні дослідів з підбору найбільш ефективних реагентів у процесі очищення конкретної стічної води, а також для визначення їх оптимальних доз використовувався метод Джар-тест. Сутність методики полягає в тому, ще в лабораторних умовах здійснюється імітачія процесу утворення пластівиів, який характерний для промислових установок очищення стічної води.

Ключові слова: стічні води, очищення, коагулячія, кольоровість, коагулянти, флокулянти.

Вступ. Можливість використання прісної води як природної сировини для потреб людства є актуальною проблемою для багатьох країн світу. Наявність якісної питної води - глобальна проблема сучасної цивілізації і пов'язана вона 3 тим, що запаси прісної води дуже обмежені. Основна маса прісної води повертається в кругообіг, однак надходить вона забрудненою і потребує якісного та вартісного очищення. Комплексний підхід до проблем економії води, охорони водойм від шкідливих забруднень, ретельного очищення побутових та стічних вод дасть змогу зменшити антропогенне забруднення водних ресурсів і сприятиме вихованню в кожній людині культури поводження з водою [1]. В процесі використання вода забруднюється речовинами мінерального та органічного походження. Промислові стічні води в основному забруднені відходами та викидами конкретних виробництв, У зв'язку з чим кількісний і якісний склад їх є різноманітним і залежить від галузі промисловості й технологічних процесів, які впроваджені на виробництві [2]. Надзвичайно актуальною проблемою сьогодення $є$ розробка ефективних методів очищення стічних вод від забруднення різноманітними барвниками, основним джерелом потрапляння яких у стічні води $є$ текстильна, харчова та хімічна промисловість.

Аналіз робіт сучасних дослідників показує, що методи очищення стічних вод від барвників постійно удосконалюються 3 підвищенням їх ефективності, спрощенням у виконанні, в напрямі пошуку дешевших та безпечніших реагентів. Для видалення різного типу барвників зі стічних вод не тільки розроблюються нові методи, а й синтезуються нові типи сорбентів, флокулянтів, коагулянтів.

У роботі [3] авторами на прикладі стічних вод, забруднених барвником аніонним червоним, експериментально доведено, що рідкі стоки, які містять барвники, можуть бути ефективно очищені адсорбцією на бентонітах та палигорськітах. Вибір для досліджень саме цих сорбентів обумовлений тим, 
що їх вартість $\epsilon$ невеликою порівняно з вартістю інших сорбентів, а сорбційна ємність достатньою для їх використання в природоохоронних технологіях.

Дослідниками [4] було розроблено новий нановолокнистий адсорбент із поліетилсульфону, призначений для видалення барвників. Ефективність його доведена на прикладі сорбції барвника метиленового синього 3 водних розчинів.

В красильних виробництвах найчастіше використовуються розчинні барвники, видалення яких зі стічних вод $\epsilon$ найбільш актуальним питанням. В роботі [5] вивчалася сорбція розчинних барвників, таких як прямого блакитного, кислотного червоного, яскравоблакитного на хітинвмісних комплексах, що були отримані 3 відходів біотехнологічного виробництва лимонної кислоти. Автором було проведено кількісне оцінювання величини сорбції та надано рекомендації щодо застосування комплексів для очищення водних розчинів у широких межах $\mathrm{pH}$.

Авторами [6] досліджувався новий сорбент на основі сапоніту і магнетиту (від 3 до 10 мас.\%). Показано, що використання магнітонаповнених сорбентів дає змогу очищати робочі середовища від барвників 3 високою ефективністю, яка становить близько 90-96 \%.

В іншій роботі [7] вивчався процес вилучення зі стічних промислових вод активного яскраво-помаранчевого барвника КХ. За допомогою квантово-хімічних розрахунків було доведено доцільність використання для цього процесу реактиву Фентона. На основі проведених експериментальних досліджень запропоновано механізм окиснення активного яскраво-помаранчевого барвника КХ системою фото-Фентон.

Авторами [8] вивчалися особливості процесів вилучення барвників, а саме брому фенолового синього при використанні технології флотоекстракції. На основі термодинамічних розрахунків було встановлено, що формування комплексу між йонами барвника та ПАР відбувається самочинно і не потребує накладання зовнішніх сил.

У статті [9] авторами розглядався реальний i економічно вигідний метод, який дає можливість отримати нанодисперсний $\mathrm{TiO}_{2} 3$ розвиненою питомою площею поверхні і високою фотокаталітичною активністю щодо барвників аніонного і катіонного типу.

В роботі [10] авторами було запропоновано використання керамічної ультрафільтра- ційної мембрани для очищення високолужних стічних вод, що забезпечило високу ефективність процесу очищення, а саме: збільшення тривалості фільтроциклу та підвищення коефіцієнта затримки.

В процесах очищення стічних вод від різного типу барвників широко використовуються та постійно удосконалюються коагуляційні та флокуляційні методи. Хімічна коагуляція - це найбільш ефективний і надійний метод видалення зважених частинок з природних і стічних вод, що також видаляє розчинені фракції деяких компонентів, знижує кольоровість вихідної води, вміст фосфатів у побутових і промислових стічних водах $[11,12]$.

При комплексному підході до очищення стічних вод від барвників дослідники [13] застосовували деструктивні методи очищення 3 використанням попередньої коагуляційної обробки з метою видалення колоїдної системи та основної частини барвника до $(90 \%)$, а доочищення стоків реалізовували фотоокисними методами.

Як коагулянти для очищення водних розчинів найчастіше використовують солі алюмінію та заліза. Коагулянти здатні гідролізуватися у воді з утворенням різних коагуляційних структур, які характеризуються високими адсорбційними та адгезійними властивостями. Авторами [14] доведено, що незначна кількість флокулянтів, введена у водний розчин, на додаток до типових коагулянтів, сприяє утворенню пластівців більшого розміру, що пришвидшує процес відстоювання i покращує якість води після фільтрації, а також стабілізує очищення і підвищує ефективність роботи обладнання. Як флокулянти використовують різноманітні неорганічні й органічні реагенти природного та синтетичного походження.

Відомо, що застосування неорганічних реагентів на основі солей алюмінію та заліза для процесу коагуляції сприяе збільшенню кількості залишкових іонів цих металів у воді після процесу очищення. Експериментальні та теоретичні дослідження в напрямі знешкодження залишкових іонів в очищеній воді проводяться в багатьох дослідницьких групах, які працюють в різних країнах світу [15]. На особливу увагу нині заслуговує напрям створення коагуляційно-флокуляційної моделі очищення 3 використанням неорганічних коагулянтів у комплексі з різними природними екологічно безпечними реагентамифлокулянтами [16-18]. 
У зв'язку з цим актуальним є питання вивчення флокуляційних властивостей хітозану в комплексі 3 неорганічними коагулянтами для процесів очищення забарвлених органічними барвниками розчинів. Хітозан $є$ позитивно зарядженим природним поліелектролітом, який може бути застосований у процесах флокуляції заряджених зважених частинок при обробці води. Відомо, що хітозан та його похідні виявляють спорідненість до важких металів та хелатні властивості і знайшли широке застосування як сорбенти [19, 20], але їх застосування як флокулянтів потребує додаткового теоретичного й експериментального дослідження. Тому дослідження можливості їх використання як флокулянтів - це перспективний напрям у розробці ефективних екологічно безпечних методів очищення та доочищення води.

Метою роботи $є$ дослідження впливу умов проведення коагуляційного та флокуляційного процесів на ступінь очищення забарвлених розчинів, визначення оптимальних доз реагентів та розробка рекомендацій для комплексного очищення забарвлених розчинів 3 використанням природного флокулянта хітозану в комплексі 3 неорганічними коагулянтами.

Матеріали та методи дослідження. Як об'єкт дослідження використовували модельні зразки забарвленої води, наближені до стічних вод текстильних підприємств України, а саме, 3 концентрацією барвника активного-синього (3СВТ) від 20 до 100 мг/дм ${ }^{3}$. Для приготування забарвлених модельних розчинів розчиняли 0,12 г барвника в 1 дм ${ }^{3}$ дистильованої води і використовували цей розчин як вихідний для приготування модельних розчинів 3 концентрацією 20 мг/дм ${ }^{3}$.

Як коагулянти використовувалися $10 \%$ розчини солей алюмінію та заліза, а саме: $\mathrm{Al}_{2}\left(\mathrm{SO}_{4}\right)_{3} \cdot 18 \mathrm{H}_{2} \mathrm{O}$, сульфат алюмінію рідкий (ALS) та розчин сульфату заліза (PIX-318). У ході експерименту було проведено порівняння ефективності очищення зразків модельних забарвлених вод 3 використанням коагулянтів на основі алюмінію та заліза та при їх комплексній дії з флокулянтом.

Як флокулянт використовували 1 \% розчин природного біополімеру хітозану (виробництва ЗАО «Біопрогрес» зі ступенем деацетилювання 82 \%). Хітозан - це природний органічний амінополісахарид 3 високою молекулярною масою і високою щільністю заря- ду. Для приготування 1 \% розчину флокулянта попередньо наважку хітозану масою 1 г розчиняли в $1 \mathrm{~cm}^{3}$ льодяної ацетатної кислоти і доводили об'єм дистильованою водою до $100 \mathrm{~cm}^{3}$ при постійному перемішуванні.

Для визначення кольоровості досліджуваних розчинів методом калібрувального графіка використовували однопроменевий спектрофотометр Ulab 1023 діапазоном довжин хвиль 325-1000 нм.

В процесі підбору найбільш ефективних реагентів для очищення модельних забарвлених розчинів, а також для визначення оптимальної дози коагулянтів i флокулянта $\left(\mathrm{Me} /\right.$ дм$\left.^{3}\right)$ застосовували метод пробної коагуляції - Джар-тест (JAR-test). Цей метод імітує виробничий процес і дає можливість не тільки визначити ефективну дозу коагулянта та флокулянта, але й встановити оптимальне значення рН і мінімальний час, який потрібен для утворення пластівців та осадження або спливання їх у вигляді осаду. При цьому також проводиться дослідження якості обробленої води після відстоювання. 3 шести досліджуваних доз коагулянта або флокулянта вибирається та, що сприяє утворенню більш щільного осаду 3 хорошими седиментаційними властивостями [21-23].

В лабораторних умовах використовувалась стаціонарна установка для Джар-тесту (флокулятор 2000 Kemira), удосконалена в аналітично-хімічній лабораторії кафедри хімічних технологій та водоочищення ЧДТУ [24, 25], схема якої зображена на рисунку 1.

Установка складається 3 шести лабораторних стаканів об'ємом 1 дм³ (2-7), призначених для одночасного дослідження рівної кількості проб води, обладнана механічними мішалками (9-14) 3 регульованими швидкістю обертання і часом перемішування, що здійснюється за допомогою флокулятора (1). Прилад додатково обладнаний $\mathrm{pH}$ електродом (8) для контролю рівня $\mathrm{pH}$ у досліджуваних зразках води.

Результати та їх обговорення. Першим етапом експериментальної частини роботи було визначення мінімальної робочої дози (Ме/дм $\left.{ }^{3}\right)$ коагулянтів та флокулянтів. Враховуючи те, що досліджувані зразки характеризуються середнім ступенем забарвлення (20 мг/дм $\left.{ }^{3}\right)$, було протестовано діапазон доз від 20 до $70 \mathrm{мг/дм}{ }^{3}$ для коагулянтів на основі алюмінію $\left(\mathrm{Al}_{2}\left(\mathrm{SO}_{4}\right)_{3} \cdot \mathrm{nH}_{2} \mathrm{O}\right.$ і ALS) та від 10 до $60 \mathrm{мг} /$ дм $^{3}$ для коагулянта на основі заліза (PIX-318). 


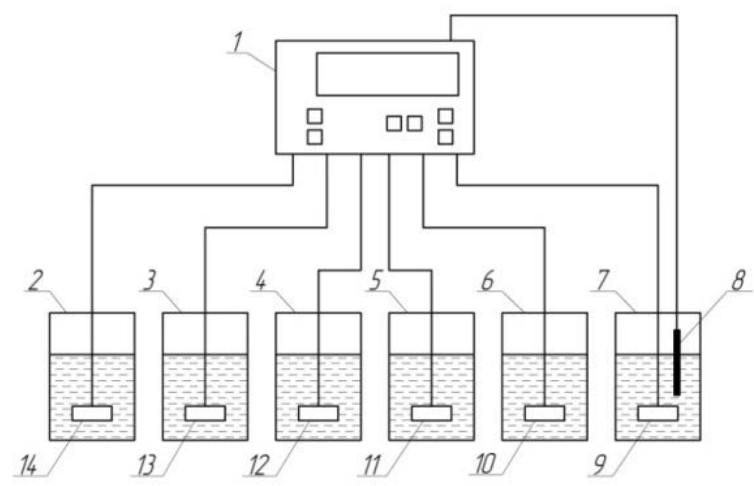

1 - флокулятор 2000 Kemira; 2-7 - лабораторні стакани місткістю 1 дм³; 8 - pН електрод; 9-14 - механічні мішалки

Рисунок 1 - Лабораторна установка для проведення Джар-тесту

В шість стаканів, заповнених модельними зразками забарвлених розчинів 3 концентрацією $20 \mathrm{мг} /$ дм $^{3}$ барвника 3СВТ, вводили дози коагулянта від 20 до 70 мг/дм ${ }^{3}$ з кроком $10 \mathrm{мг} /$ дм $^{3}$, потім розчини перемішували зі швидкістю 140 об/хв впродовж двох хвилин. Цей період відповідає стадії гідролізу коагулянта. Далі швидкість перемішування було знижено до 50 об/хв і впродовж 10 хв відбувалося утворення пластівців. Візуальні спостереження за процесом утворення та осідання осаду дали змогу встановити оптимальну дозу коагулянта та оптимальні умови процесу для утворення пластівців доволі великих розмірів. Дослідження проводилися в нейтральному середовищі $3 \mathrm{pH}=6-8$. Регулювання $\mathrm{pH}$ проводили додаванням еквівалентної кількості 5-10\% розчинів $\mathrm{NaOH}$ або $\mathrm{HCl}$ до кількості введеної безводної солі коагулянта. Наступною стадією дослідження $є$ період седиментації, тобто осадження пластівців у вигляді оса- ду. Оцінювання якості очищення зразків було проведено через 60 хв та через добу після початку процесу седиментації шляхом відбору проб з кожної склянки на одній і тій же глибині відстояного шару води, з подальшим їх аналізом на вміст залишкових концентрацій забруднюючих речовин.

Одержані графічні залежності, які зображено на рисунку 2, показують, що оптимальна доза для ефективного очищення модельного розчину 3 концентрацією барвника активного-синього 20 мг/дм ${ }^{3}$ при застосуванні коагулянтів становить: 40 мг/дм ${ }^{3}$ для PIX-318 та $\mathrm{Al}_{2}\left(\mathrm{SO}_{4}\right)_{3} \cdot \mathrm{nH}_{2} \mathrm{O}$ і 20 мг/дм ${ }^{3}$ для ALS. При збільшенні часу проведення седиментації до 24 год оптимальна доза для коагулянта PIX318 не змінюється $\left(40 \mathrm{Mг} /\right.$ дм $\left.^{3}\right)$, для $\mathrm{Al}_{2}\left(\mathrm{SO}_{4}\right)_{3} \cdot \mathrm{nH}_{2} \mathrm{O}$ i ALS збільшується до 50 мг/дм ${ }^{3}$ та до $60 \mathrm{мг} /$ дм $^{3}$ відповідно (рисунок 3).

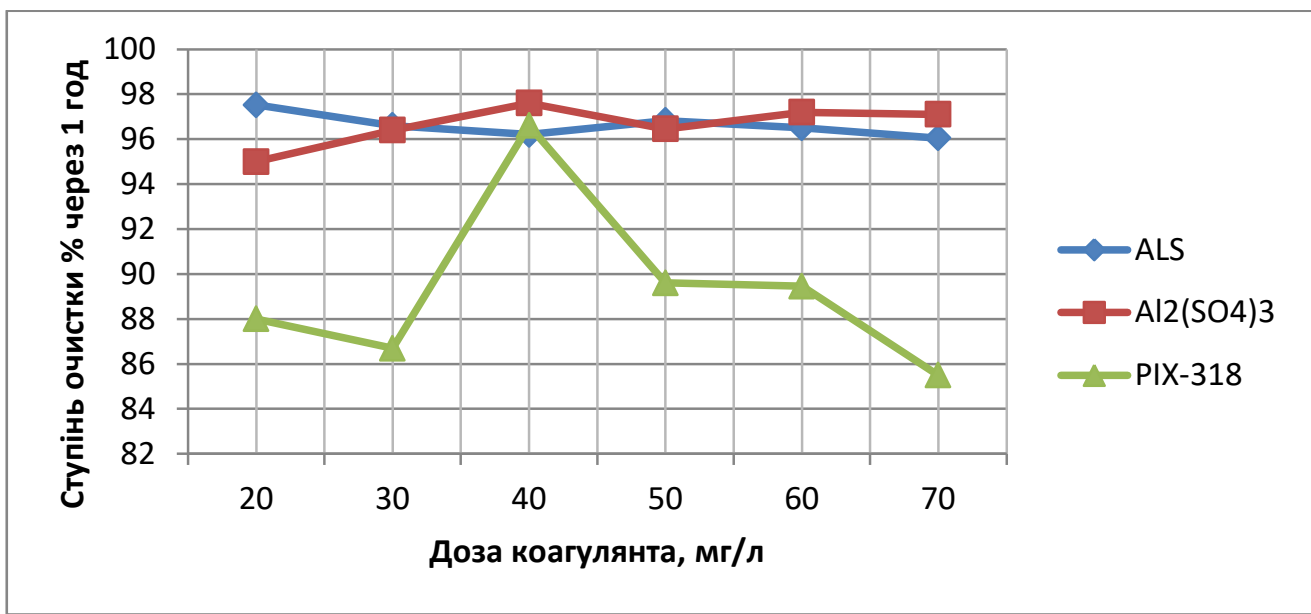

Рисунок 2 - Залежність ступеня очистки забарвлених зразків води 3 концентрацісю барвника 20 мг/дм³ від дози коагулянта (тривалість процесу седиментації - 60 хв)

(C) Т. В. Солодовнік, Н. М. Толстопалова, Н. М. Фоміна, І. К. Якименко, 2019 DOI: 10.24025/2306-4412.3.2019.167654 


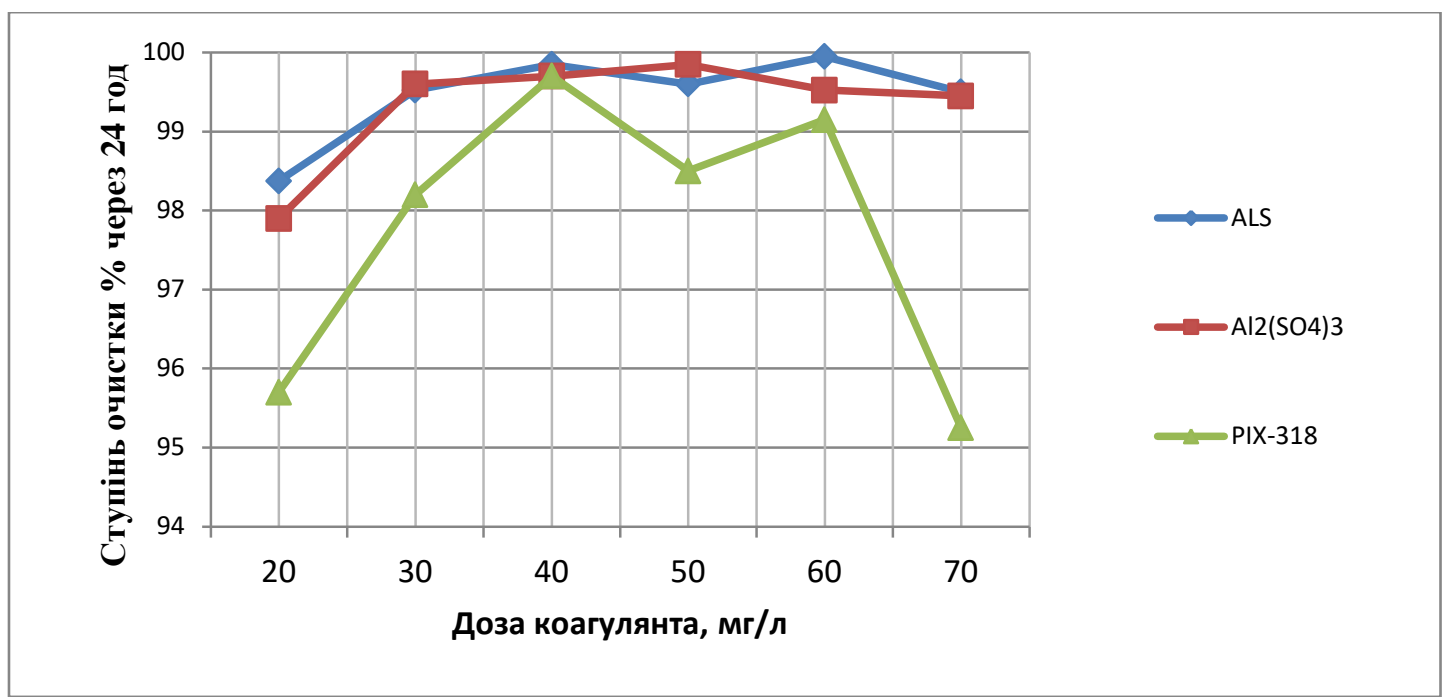

Рисунок 3 - Залежність ступеня очистки забарвлених зразків води 3 концентрацісю барвника 20 мг/дм³ від дози коагулянта (тривалість процесу седиментації - 24 год)

Завданням наступного етапу дослідження було визначення оптимальної дози флокулянта-хітозану в комплексі з кожним із коагулянтів, що були взяті у кількості, яка відповідає їх визначеним на попередньому етапі, після 60 хв седиментації, оптимальним дозам. Для цього усі шість скляних стаканів були заповнені однаковим об'ємом досліджуваної води (1 дм $\left.{ }^{3}\right)$ і додана одна й та ж оптимальна доза коагулянта. Після інтенсивного перемішування зі швидкістю 140 об/хв впродовж 2 хв у склянки було введено дози $1 \%$ розчину флокулянта-хітозану в інтервалі від 0,2 до $3,4 \mathrm{~cm}^{3}$, що відповідає вмісту хітозану від 2 до $34 \mathrm{мг} /$ дм $^{3}$, при цьому перший стакан залишався контрольним, тобто без додавання флокулянта. Після цього експеримент проводили аналогічно тому, який описаний для коагулянтів, і оцінювання якості очищення проводилося через 60 хв та через 24 год після початку процесу седиментації.

Аналіз отриманих графічних залежностей дав можливість визначити ефективну дозу флокулянта та оптимальні умови його застосування в комплексі з різними коагулянтами.

Отримані графічні залежності, зображені на рисунку 4, свідчать про те, що оптимальна доза флокулянта-хітозану, визначена через 60 хв після початку процесу та при використанні його разом 3 різними коагулянтами, становить $20 \mathrm{мг} /$ дм $^{3}-3$ PIX-318 i $\mathrm{Al}_{2}\left(\mathrm{SO}_{4}\right)_{3} \cdot \mathrm{nH}_{2} \mathrm{O}$ та 34 мг/дм ${ }^{3}-3$ ALS.
Збільшення часу проведення процесу седиментації до 24 год сприяє зменшенню дози хітозану до $6 \mathrm{m \Gamma} /$ дм $^{3}$ при дії 3 $\mathrm{Al}_{2}\left(\mathrm{SO}_{4}\right)_{3} \cdot \mathrm{nH}_{2} \mathrm{O}$ та до $2 \mathrm{мг} /$ дм $^{3}-3$ PIX-318, а при дії в комплексі 3 ALS оптимальна доза залишається незмінною - 34 мг/дм ${ }^{3}$ (рисунок 5).

Також у результаті експерименту встановлено, що збільшення дози флокулянтахітозану сприяє утворенню пластівців більшого розміру, а це, в свою чергу, пришвидшує процес осадження, коагулянти ALS та $\mathrm{Al}_{2}\left(\mathrm{SO}_{4}\right)_{3} \cdot \mathrm{nH}_{2} \mathrm{O} 3$ хітозаном утворюють агрегати, які з часом руйнуються, на відміну від агрегатів, що утворюються 3 PIX-318, які утворюють стійкі сполуки, а ступінь очищення при цьому досягає практично $100 \%$.

При дослідженні якості води, яке проводилося після завершення процесу коагуляції, також було встановлено, що в результаті використання коагулянта PIX-318 очищена вода містить деяку кількість залишкових іонів $\mathrm{Fe}^{3+}$, наявність яких збільшує мутність та кольоровість розчинів (таблиця 1). У той же час додавання незначної кількості флокулянта-хітозану, а саме $6 \mathrm{мг} /$ дм $^{3}$, дає змогу знизити вміст заліза вдвічі, а при використанні оптимальної дози флокулянта - повністю вилучити його (таблиця 2). На нашу думку, це пов'язано $з$ хелатними властивостями хітозану, які він виявляє до іонів важких металів $[19,20]$. 


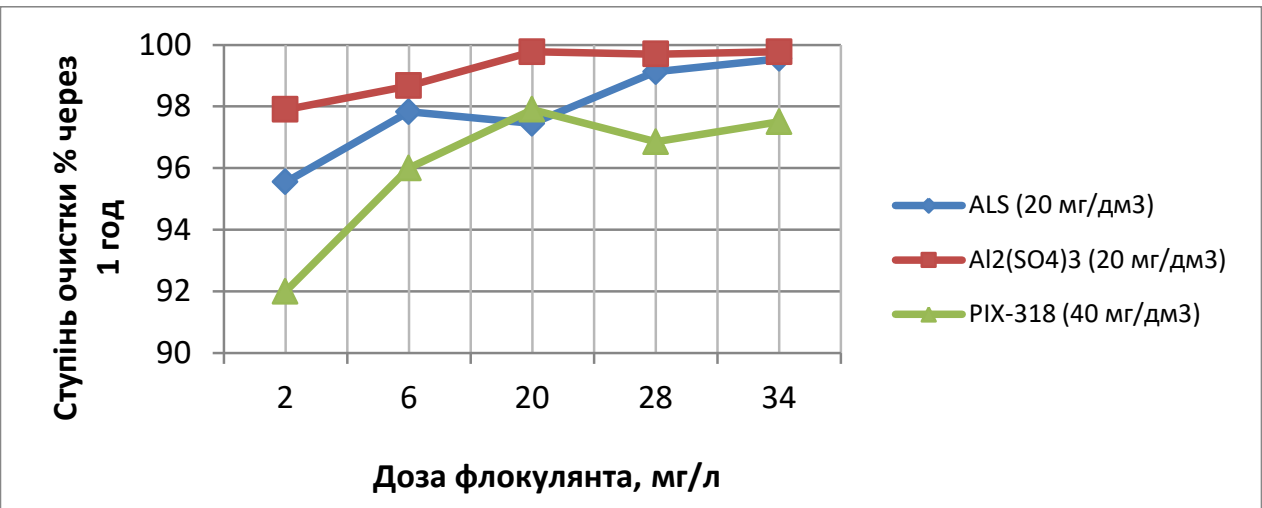

Рисунок 4 - Залежність ступеня очистки забарвлених стічних вод з вмістом барвника 20 мг/дм від дози флокулянта при дії в комплексі з різними типами коагулянтів

(тривалість процесу седиментації - 60 хв)

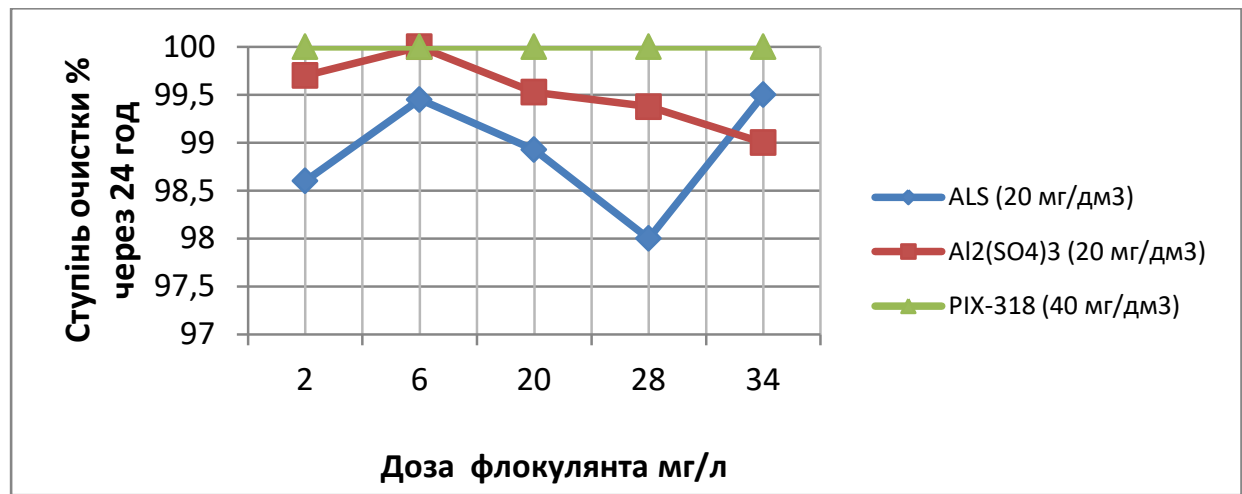

Рисунок 5 - Залежність ступеня очистки забарвлених стічних вод 3 вмістом барвника 20 мг/дм від дози флокулянта при дії в комплексі з різними типами коагулянтів

(тривалість процесу седиментації - 24 год)

Таблиця 1 - Вміст залишкових $\mathrm{Fe}^{3+}$-іонів у очищеній воді після процесу коагуляції 3 коагулянтом PIX-318

\begin{tabular}{|c|c|}
\hline Доза PIX-318, мг/дм $^{3}$ & Концентрація $\mathrm{Fe}^{3+}$-іонів, мг/ дм \\
\hline 10 & 0 \\
\hline 20 & 0,014 \\
\hline 30 & 0,014 \\
\hline 40 & 0,144 \\
\hline 50 & 0,38 \\
\hline 60 & 0,524 \\
\hline
\end{tabular}

Таблиця 2 - Вміст залишкових $\mathrm{Fe}^{3+}$ іонів при комплексній дії флокулянта-хітозану 3 коагулянтом PIX-318 (40 мг/дм³)

\begin{tabular}{|c|c|}
\hline Доза флокулянта, мг/дм & Концентрація $\mathrm{Fe}^{3+}$-іонів, мг/ дм $^{3}$ \\
\hline 2 & 0,66 \\
\hline 6 & 0,03 \\
\hline 10 & 0 \\
\hline 20 & 0 \\
\hline 28 & 0 \\
\hline 34 & 0 \\
\hline
\end{tabular}

(C) Т. В. Солодовнік, Н. М. Толстопалова, Н. М. Фоміна, І. К. Якименко, 2019 DOI: $10.24025 / 2306-4412.3 .2019 .167654$ 
Висновки. В результаті виконання дослідницької роботи було проаналізовано процес очищення забарвлених модельних розчинів, наближених до стічних вод текстильних підприємств України, методами коагуляції та флокуляції з використанням різних типів коагулянтів та природного флокулянта. Як коагулянти використовували: кристалогідрат сірчанокислого алюмінію $\left(\mathrm{Al}_{2}\left(\mathrm{SO}_{4}\right)_{3} \cdot 18 \mathrm{H}_{2} \mathrm{O}\right)$, розчин сульфату хлориду заліза (PIX-318) та сульфат алюмінію рідкий (ALS). Як флокулянт використовували природний біополімер хітозан (виробництва ЗАО «Біопрогрес» 3 i ступенем деацетилювання 82 \%).

В процесі дослідження коагуляційного способу очищення модельних розчинів було визначено оптимальні дози коагулянтів та флокулянта-хітозану для розчинів 3 концентрацією барвника $20 \mathrm{мг} /$ дм $^{3}$, що становлять для коагулянтів PIX-318 i $\mathrm{Al}_{2}\left(\mathrm{SO}_{4}\right)_{3} \cdot \mathrm{nH}_{2} \mathrm{O}$ 40 мг/дм ${ }^{3}$ a ALS - 20 мг/дм ${ }^{3}$, а для флокулянта-хітозану при використанні його в комплек-

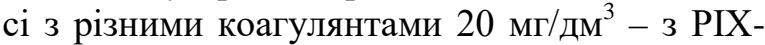
$318 \mathrm{i} \mathrm{Al}_{2}\left(\mathrm{SO}_{4}\right)_{3} \cdot \mathrm{nH}_{2} \mathrm{O}$ та $34 \mathrm{мг} /$ дм $^{3}-3$ ALS.

При порівнянні ефективності використання коагулянтів встановлено, що ступінь очищення методом коагуляції, з використанням будь-якого 3 досліджуваних коагулянтів, при збільшенні тривалості проведення процесу седиментації теж збільшується.

Також зафіксовано, що при застосуванні залізовмісного коагулянта в очищених зразках води наявний залишковий вміст іонів заліза (III), та доведено, що додавання визначеної дози флокулянта-хітозану дає змогу повністю вилучити іони заліза з очищеної води.

Доведено, що використання хітозану як флокулянта сприяє утворенню пластівців значно більшого розміру, що пришвидшує процес седиментації.

Встановлено, що ступінь очищення забарвлених модельних розчинів залежить від концентрації доданих коагулянтів та флокулянта, а також від ступеня забрудненості води і від тривалості осадження.

\section{Список літератури}

[1] I. М. Астрелін, та Х. Ратнавіри, Фізикохімічні методи очищення води. Керування водними ресурсали: підручник. 2015.

[2] Т. В. Солодовнік, та Г. С. Столяренко, "Вирішення актуальних питань водопідготовки та очищення стічних вод науков- цями міжнародного рівня в рамках проекту "Водна Гармонія", Вісник Черкаського державного технологічного університеmy, № 1, с.137-149, 2017 (Технічні науки).

[3] I. М. Петрушка, Г. З. Леськів, та Г. І. Плахтій, "Очищення стічних вод від барвників природними сорбентами", Bicник Національного університету "Львівська політехніка", № 488, с. 230-233, 2003.

[4] Shahin Homaeigohar, Ahnaf Usman Zillohu, Ramzy Abdelaziz, Mehdi Keshavarz Hedayati, and Mady Elbahri, in Materials A novel nanohybrid nanofibrous adsorbent for water purification from dye pollutants, vol. 9, no. 10,848 , pp. 1-16, 2016.

[5] Т. В. Солодовник, "Сорбция растворимых красителей на хитинсодержащих комплексах", Химия и технология воды, 25 (4), c. 342-349, 2003.

[6] N. Mykhailenko, O. Makarchuk, T. Dontsova, S. Gorobets, and I. Astrelin, "Purification of aqeous media by magnetically operated saponite sorbents", Eastern European Journal of Enterprise Technologies, 4, pp. 13-20, 2015.

[7] I. Kosogina, I. Astrelin, G. Krimets, and N. Vereshchuk, "The process of wastewater treatment with advanced oxidation methods to remove dye", Chemistry \& Chemical Technology, 8 (3), pp. 365-369, 2014.

[8] T. Obushenko, N. Tolstopalova, O. Kulesha, and I. Astrelin, "Thermodynamic studies of bromphenol blue removal from water using solvent sublation", Chemistry \& Chemical Technology, 10 (4), pp. 515-518, 2016.

[9] T. A. Dontsova, I. Ivanenko, and I. Astrelin, "Synthesis and characterization of titanium(IV) oxide from various precursors", Springer Proceedings in Physics, 167, pp. 275-293, 2015.

[10] В. В. Гончарук, Т. Ю. Дульнева, Д. Д. Кучерук, та Г. М. Тіторук, "Спосіб очищення стічних вод від прямих барвників", Патент № 78892, Квіт. 10, 2013.

[11] А. К. Запольский, и А. А. Баран, Коагулянты и флокулянты в прочессах очистки воды: Свойства. Получение. Применение. Ленинград: Химия, 1987.

[12] А. И. Мацнев, Водоотведение на промышленных предприятиях. Львов: Вища шк. Изд-во при Львов. ун-те, 1986. 
[13] I. В. Косогіна, I. М. Астрелін, та Н. М. Толстопалова, "Комплексне очищення стічних вод від барвників", на III Всеукр. з '̈зді екологів з міжнар. участю: зб. наук. ст., т. 2. Вінниця, 2011, c. 601.

[14] І. К. Якименко, та Т. В. Солодовнік, "Дослідження процесу коагуляції та процесу очищення мутних та забарвлених розчинів при використанні різного типу коагулянтів", на VII Міжнар. конф. студентів, аспірантів та молодих вчених з хімії та хім. технології: зб. тез доп. Київ, 2018, c. 169.

[15] F. W. Pontius, "Chitosan as a drinking water treatment coagulant", American Journal of Civil Engineering, vol. 4, iss. 5, pp. 205-215, 2016.

[16] Sara Ann Fast, Bahareh Kokabian, and Veera Gnaneswar Gude, "Chitosan enhanced coagulation of algal turbid waters comparison between rapid mix and ultrasound coagulation methods", Chemical Engineering Journal, 244, pp. 403-410, 2014.

[17] D. Zeng, J. Wu, and J. F. Kennedy, "Application of a chitosan flocculant to water treatment", Carbohydrate Polymers, vol. 71, no. 1, pp. 135-139, 2008.

[18] F. Renault, B. Sancey, P. M. Badot, and G. Crini, "Chitosan for coagulation/ flocculation processes - an eco-friendly approach", European Polymer Journal, 45, pp. 1337-1348, 2009.

[19] Dorota Kołodyńska, "Chitosan as an effective low-cost sorbent of heavy metal complexes with the polyaspartic acid", Chemical Engineering Journal, vol. 173, iss. 2, pp. 520-529, 2011.

[20] W. S. Wan Ngah, and M. A. K. M. Hanafiah, "Removal of heavy metal ions from wastewater by chemically modified plant wastes as adsorbents: a review", Bioresource Technology, 99, pp. 3935-3948, 2008.

[21] P. Aragonés-Beltrán, J. A. Mendoza-Roca, A. Bes-Piá, M. García-Melón, and E. ParraRuiz, "Application of multicriteria decision analysis to jar-test results for chemicals selection in the physical-chemical treatment of textile wastewater", Journal of Hazardous Materials, vol. 164, iss. 1, pp. 288-295, 2009.

[22] Herbert E. Hudson Jr, and E. G. Wagner, "Conduct and uses of jar tests", Journal of
American Water Works Association, vol. 73, iss. 4, pp. 218-223, 1981.

[23] B. Tassinari, S. Conaghan, B. Freeland, and I. W. Marison, "Application of turbidity meters for the quantitative analysis of flocculation in a jar test apparatus", Journal of Environmental Engineering, vol. 141, iss. 9, 2015.

[24] T. V. Solodovnik, H. S. Stolyarenko, and A. A. Slis, "Prospects of using complex coagulation systems based on chitosan in water treatment processes", на V Междунар. водном форуме "Водные ресурсы и климam", ч. 2. Минск, Республика Беларусь, 2017, c. 87-90.

[25] Т. В. Солодовнік, Фізична та колоїдна хімія: лабораторний практикум. Черкаси: ЧДТУ, 2014.

\section{References}

[1] I. M. Astrelin, and Kh. Ratnaviry, Physicochemical methods of water purification. Water management: textbook. 2015 [in Ukrainian].

[2] T. V. Solodovnik, and H. S. Stoliarenko, "Solution of topical issues of water treatment and sewage purification by scientists of international level within the framework of the "Water Harmony" project", Visnyk Cherkaskogo derzhavnogo tekhnologichnogo universytetu, no. 1, pp. 137-149, 2017 [in Ukrainian].

[3] I. M. Petrushka, H. Z. Leskiv, and H. I. Plakhtii, "Purification of waste water from dyes by natural sorbents", Visnyk Natsionalnoho universytetu "Lvivska politekhnika", no. 488, pp. 230-233, 2003 [in Ukrainian].

[4] Shahin Homaeigohar, Ahnaf Usman Zillohu, Ramzy Abdelaziz, Mehdi Keshavarz Hedayati, and Mady Elbahri, in Materials A novel nanohybrid nanofibrous adsorbent for water purification from dye pollutants, vol. 9, no. 10, 848, pp.1-16, 2016.

[5] T. V. Solodovnik, "Sorption of soluble dyes on chitin-containing complexes", Khimiya $i$ tekhnologiya vody, 25 (4), pp. 342-349, 2003 [in Russian].

[6] N. Mykhailenko, O. Makarchuk, T. Dontsova, S. Gorobets, and I. Astrelin, "Purification of aqeous media by magnetically operated saponite sorbents", Eastern European 
Journal of Enterprise Technologies, 4, pp. 13-20, 2015.

[7] I. Kosogina, I. Astrelin, G. Krimets, and N. Vereshchuk, "The process of wastewater treatment with advanced oxidation methods to remove dye", Chemistry \& Chemical Technology, 8 (3), pp. 365-369, 2014.

[8] T. Obushenko, N. Tolstopalova, O. Kulesha, and I. Astrelin, "Thermodynamic studies of bromphenol blue removal from water using solvent sublation", Chemistry \& Chemical Technology, 10 (4), pp. 515-518, 2016.

[9] T. A. Dontsova, I. Ivanenko, and I. Astrelin, "Synthesis and characterization of titanium (IV) oxide from various precursors", Springer Proceedings in Physics, 167, pp. 275-293, 2015.

[10] V. V. Honcharuk,

T. Yu. Dulneva, D. D. Kucheruk, and H. M. Titoruk, "Method of purification of waste water from direct dyes", Patent no. 78892, Apr. 10, 2013 [in Ukrainian].

[11] A. K. Zapolskyi, and A. A. Baran, Coagulants and flocculants in water purification processes: Properties. Receiving. Application.. Leningrad: Khimiya, 1987 [in Russian].

[12] A. I. Matsnev, Water disposal in industrial enterprises. Lvov: Vyshcha shk. Izd-vo pri Lvov. un-te, 1986 [in Russian].

[13] I. V. Kosohina, I. M. Astrelin, and N. M. Tolstopalova, "Complex wastewater purification from dyes", in III All-Ukr. Environmental Convention with Internat. Participation: coll. of sci. papers, vol. 2. Vinnytsia, 2011, p. 601 [in Ukrainian].

[14] I. K. Yakymenko, and T. V. Solodovnik, "Investigation of the process of coagulation and the process of purification of muddy and colored solutions using different types of coagulants", in VII Internat. Conf. of Students, Graduate Students and Young Scientists in Chemistry and Chem. Technology: collected abstracts. Kyiv, 2018, p. 169 [in Ukrainian].

[15] F. W. Pontius, "Chitosan as a drinking water treatment coagulant", American Journal of Civil Engineering, vol. 4, iss. 5, pp. 205-215, 2016.

[16] Sara Ann Fast, Bahareh Kokabian, and Veera Gnaneswar Gude, "Chitosan enhanced coagulation of algal turbid waters - comparison between rapid mix and ultrasound coagulation methods", Chemical Engineering Journal, 244, pp. 403-410, 2014.

[17] D. Zeng, J. Wu, and J. F. Kennedy, "Application of a chitosan flocculant to water treatment", Carbohydrate Polymers, vol. 71, no. 1, pp. 135-139, 2008.

[18] F. Renault, B. Sancey, P. M. Badot, and G. Crini, "Chitosan for coagulation/ flocculation processes - an eco-friendly approach", European Polymer Journal, 45, pp. 1337-1348, 2009.

[19] Dorota Kołodyńska, "Chitosan as an effective low-cost sorbent of heavy metal complexes with the polyaspartic acid", Chemical Engineering Journal, vol.173, iss. 2, pp. 520-529, 2011.

[20] W. S. Wan Ngah, and M. A. K. M. Hanafiah, "Removal of heavy metal ions from wastewater by chemically modified plant wastes as adsorbents: a review", Bioresource Technology, 99, pp.3935-3948, 2008.

[21] P. Aragonés-Beltrán, J. A. Mendoza-Roca, A. Bes-Piá, M. García-Melón, and E. ParraRuiz, "Application of multicriteria decision analysis to jar-test results for chemicals selection in the physical-chemical treatment of textile wastewater", Journal of Hazardous Materials, vol. 164, iss. 1, pp. 288-295, 2009.

[22] Herbert E. Hudson Jr, and E. G. Wagner, "Conduct and uses of jar tests", Journal of American Water Works Association, vol. 73, iss. 4, pp. 218-223, 1981.

[23] B. Tassinari, S. Conaghan, B. Freeland, and I. W. Marison, "Application of turbidity meters for the quantitative analysis of flocculation in a jar test apparatus", Journal of Environmental Engineering, vol. 141, iss. 9, 2015.

[24] T. V. Solodovnik, H. S. Stolyarenko, and A. A. Slis, "Prospects of using complex coagulation systems based on chitosan in water treatment processes", in V Int. Water Forume "Water Resources and Climate", part 2. Minsk, Republic of Belarus, 2017, pp. 87-90.

[25] T. V. Solodovnik, Physical and colloidal chemistry. Cherkasy: ChDTU, 2014 [in Ukrainian]. 
T. V. Solodovnik ${ }^{1}$, Ph. D., associate professor of the department of chemical technologies and water treatment, e-mail: solodovniktetana@gmail.com

N. M. Tolstopalova ${ }^{2}$, Ph. D. (Eng.), associate professor, acting head of the department of inorganic matters technology, water purification and general chemical technology,

N. M. Fomina ${ }^{1}$, senior lecturer of the department of chemical technologies and water treatment,

I. K. Yakymenko ${ }^{1}$, student

e-mail: yakimenko97@ukr.net

${ }^{1}$ Cherkasy State Technological University

Shevchenko blvd, 460, Cherkasy, 18006, Ukraine

${ }^{2}$ National Technical University of Ukraine "Igor Sikorsky Kyiv Polytechnic Institute"

Peremohy ave., 37, Kyiv, 03056, Ukraine

\section{STUDY OF THE PROCESSES OF COLORED SOLUTIONS PURIFICATION USING INORGANIC COAGULANTS AND NATURAL FLOCULANT}

Today the problem of purification of domestic and industrial wastewater from a variety of organic and inorganic pollutants is one of the most important and topical issues in the world. The further harmonious existence of all aquatic ecosystems depends on a successful solution of this problem. In the process of work, studies on the analysis of existing methods of sewage treatment, painted with different types of dyes, and the search for efficient ways to improve them have been carried out. The coagulation process using coagulants in combination with natural and artificial flocculants is one of the effective ways of treating colored sewage. The coagulation process is usually carried out using coagulants based on aluminum and iron salts that are capable of hydrolyzing in water to form various coagulation structures with high adsorption and adhesion properties. The addition of flocculants, even in small amounts, besides conventional coagulants, promotes the faster formation of flakes, sedimentation and filtration, stabilizes the process of purification, improves the quality and efficiency of the equipment operation.

At the Department of Chemical Technologies and Water Treatment, the research of the determination of the optimal dosage of coagulants based on aluminum $\left(\mathrm{Al}_{2}\left(\mathrm{SO}_{4}\right)_{3} \cdot 18 \mathrm{H}_{2} \mathrm{O}\right.$, ALS) and iron (PIX-318) to purify colored model solutions that are similar to the sewage of Ukrainian coloring companies has been conducted. Natural amino polysaccharide - chitosan, which is offered as the effective flocculant, has been used in combination with inorganic coagulants. Being a weak cationic flocculant, chitosan has an increased efficacy of protein sedimentation compared with classical flocculants. In the process of purification of model solutions, the optimal dosages of coagulants and the flocculant - chitosan have been determined using the Jar-test method. The degree of purification of colored model solutions, from the concentrations of added coagulants and flocculant, as well as the degree of water pollution and the duration of deposition have been established. Increasing the duration of the sedimentation process allows to increase the degree of purification of colored model solutions. The advantages and disadvantages of different properties of coagulants are identified and recommendations are developed to improve the efficiency of the use of the coagulation process of purification.

Keywords: sewage, purification, coagulation, coloration, coagulants, flocculants.

Стаття надійшла 27.06.2019

Прийнято 19.07.2019

(c) Т. В. Солодовнік, Н. М. Толстопалова, Н. М. Фоміна, І. К. Якименко, 2019 DOI: $10.24025 / 2306-4412.3 .2019 .167654$ 